\title{
Imagineering, or what Images do to People: Violence and the Spectacular in the Seventeenth-Century Dutch Republic
}

\author{
Frans-Willem Korsten (D, Leiden University \\ Cornelis van der Haven (D), Ghent University \\ Inger Leemans (D), Vrije Universiteit Amsterdam \\ Karel Vanhaesebrouck (D), Université Libre de Bruxelles \\ Michel van Duijnen, Vrije Universiteit Amsterdam \\ Yannice De Bruyn (D), Ghent University, \\ Vrije Universiteit Brussel
}

This article proposes a term that is new in the field of early modern studies, imagineering, to describe a process in the seventeenth-century Dutch Republic that brought about a crucial shift in the representation of violence. This shift took place in the context of a rapidly developing consumer market with a thriving industry producing printed images. In that industry, violence became less and less a matter of the public visualization of sovereign powers. It developed instead into something that sells. Books representing violence became commodities to be bought, owned and resold. This development resulted, as we argue, in a shift from a theatrical culture of public spectacle to a spectacular culture of private consumption. This shift, in turn, coincided with a change in the execution of power. Administrations started to become less and less violent, or, rather, they made less use of the public display of violence, both real and symbolic. This implied, as Michel Foucault has extensively described, that they depended more and more on the coincidence of governmentality and people's self-administration and self-control. ${ }^{1}$ These two developments together had considerable aesthetic consequences.

Cultural History 10.1 (2021): 1-30

DOI: 10.3366/cult.2021.0229

(C) Edinburgh University Press www.euppublishing.com/cult 


\section{Cultural History}

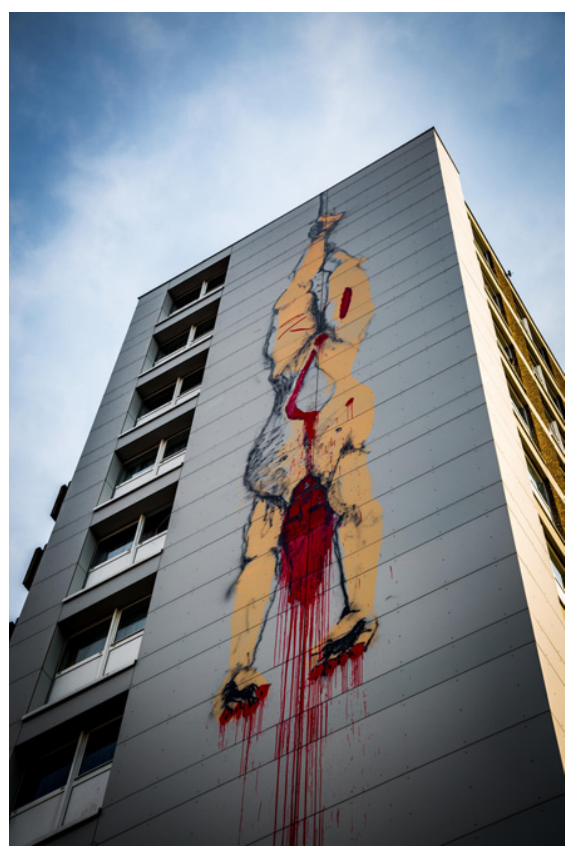

Fig. 1: Anonymous wall painting, Brigittenstraat, Brussels (2017). Copyright BRUZZ/Maarten Coosemans.

The general audience was already familiar with the spectacles organized by ruling powers - whether imperial, royal, princely or papal - and it now became acquainted with what we will call the spectacular. Whereas spectacles consisted of impressive events (entrances, fireworks, etc.), the spectacular consisted of the circulation of an impressive number of high-quality images that could be enjoyed in the private sphere. Throughout the Dutch seventeenth century, we argue, the culture of public spectacle found a perfect ally in a spectacular regime aimed at private pleasure and awe. ${ }^{2}$ The notion of imagineering enables us to understand this complex multiplication of regimes of display.

Take, for instance, the image in Figure 1 - about twenty metres long which suddenly manifested itself in the urban environment of Brussels in January 2017. ${ }^{3}$ It was painted on the wall of a block of flats in the Brigittenstraat, close to the train station Brussel-Kapellekerk.

Someone soon noticed that the sketch explicitly referred to a painting attributed to the Dutch painter Jan de Baen (Fig. 2), now exhibited in the Rijksmuseum. It was made shortly after the brothers Johan and Cornelis de Witt, the leading politicians of the Dutch Republic for two decades, 


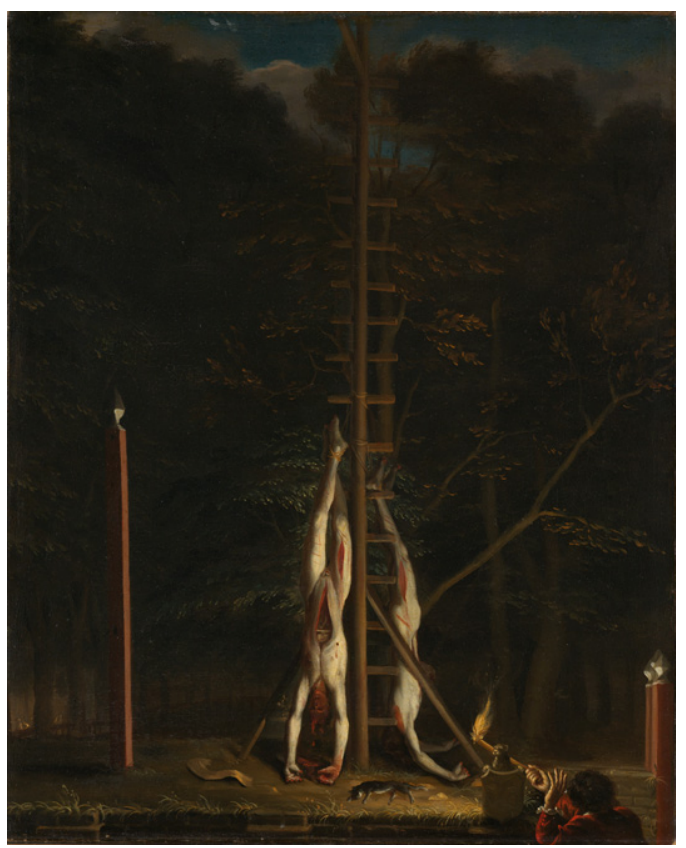

Fig. 2: Jan de Baen (attributed to), The bodies of the de Witt Brothers (around 1672-1675). Rijksmuseum Amsterdam, SK-A-15.

had been brutally assassinated in The Hague in 1672 . Their bodies were ripped to pieces and hanged, like slaughtered animals. Parts of the bodies and pieces of cloth drenched in blood were sold on the streets. This gruesome event, which took place during the 'Disaster Year' (Rampjaar) of 1672, shook the Dutch Republic and triggered a gulf of visual and textual descriptions of the scene, not only by de Baen but also by the prolific and popular engraver and pamphleteer Romeyn de Hooghe (Fig. 3). ${ }^{4}$

People wondered why the Brussels mural sketch referred to the seventeenth-century painting; others asked themselves why it had been painted here, on this wall, in this city, or how it was made. The question central to this article, however, is how this very same image came to mean something through an abundance of images broadly circulating in different media on different platforms. Few people saw the mural in its urban environment on the morning after it was made; yet it was immediately taken up in the circulation of images on the internet. In this context, it is no coincidence that the wall painting alludes to the baroque - both through the explicit reference to the de Witt murders and through the themes and style of painting in general. In our reading, 


\section{Cultural History}

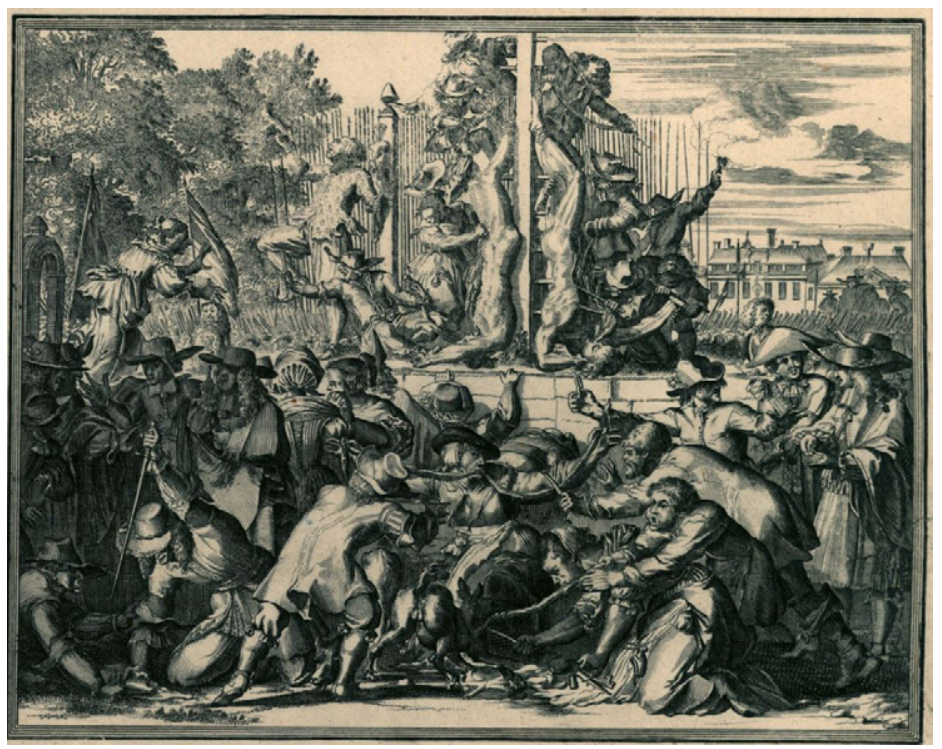

Fig. 3: Romeyn de Hooghe, Murder of the de Witt Brothers (1672) (detail of news pamphlet, fig. 6). Rijksmuseum Amsterdam, RP-P-OB-77.136.

the seventeenth-century baroque is the cradle of what we call imagineering. This article aims to unfold what this new conceptual term means, how it could help to understand early modern transformations in techniques and representation, and what consequences this new understanding could have for current theories on the history of print and media, on the public sphere, on theatricality and spectacle and on constructions of the self.

In our analyses of different seventeenth-century visual genres, we begin from the assumption that in the early modern period a tension developed between two distinct generic regimes of representing violence: the theatrical and the spectacular. We explore how the early modern period witnessed the rise of spectacles in the context of an explosively growing market - an advanced multimedia market characterized by the visual. The dynamic between the theatrical and the spectacular was most clearly visible in Dutch cities, where, in the absence of a central monarchy, the urban, republican realm consisted of a complex and intricately intertwined web of political and commercial conceptions of power. With the distinction between public space and private market becoming increasingly porous, early modern cities in the Dutch Republic functioned as a privileged visual laboratory by means of which the theatrical culture, as the sole privilege of the powerful, was gradually 


\section{Imagineering}

sidelined by a complex spectacular infrastructure. This spectacular infrastructure aimed to provide the spectator with an embodied experience that was partly private but simultaneously had a performative impact on the collective imagination.

To illustrate this shift from a general culture of theatrical display to a multifaceted spectacular culture, we have chosen the paradigmatic case of the gruesome images of the lynching of the brothers de Witt. In the Disaster Year, the Dutch Republic was invaded by the allied forces of France, England, Münster and Cologne. ${ }^{5}$ Anxiety about the invasion, coupled with discontent with the politics of the state pensionary Johan de Witt and his decision to ban the stadtholderate in perpetuity, swept the country into crisis, finally resulting in the slaughtering of the de Witt brothers on 21 August 1672 . We use 1672 as pivotal moment, showing how the afterlife of this particular historic event used familiar theatrical models and was drawn into a rapidly expanding commercial market of prints that propelled the spectacular.

\section{A printed industry: Reprinting, imprinting and the dominant theme of violence}

In 1633 a set of eighteen etchings was published under the title Les Grandes Misères et Malheurs de la Guerre, or The Great Miseries and Misfortunes of War (Fig. 4). The work, by Jacques Callot, is commonly considered a powerful first statement in the history of European art against the atrocities of war, comparable to Francisco Goya's better-known or more famous pieces in the early nineteenth century. The set attracted a wide audience, including outside of France; it started to travel through Europe in different versions. One set of the etchings was republished, for instance, in Amsterdam sometime between 1677 and 1690 under the title The Sad Miseries of War: Very Nicely and Craftily Depicted by Jacques Callot, Noble Man from Lorraine, Published by Gerrit van Schagen. ${ }^{6}$

In the considerable number of studies on these etchings, almost no attention is paid to the changes in the status and power of the press between 1633 and $1690 .{ }^{7}$ Yet although the set published at the end of the century was identical to that from 1633 , it was defined by a radically different cultural and political infrastructure. The more general problems of atrocities in war had become very concrete because the Republic had been invaded by French forces. As a consequence, Callot's etchings were taken up intertextually in entirely new sets of images, as in the set French Cruelties in Dutch Villages, 1672 (1673), by the Dutch engraver Romeyn de Hooghe (Fig. 5).

De Hooghe was active in a period of political and social crisis, with the Disaster Year as one of its highlights. Over the course of the 


\section{Cultural History}

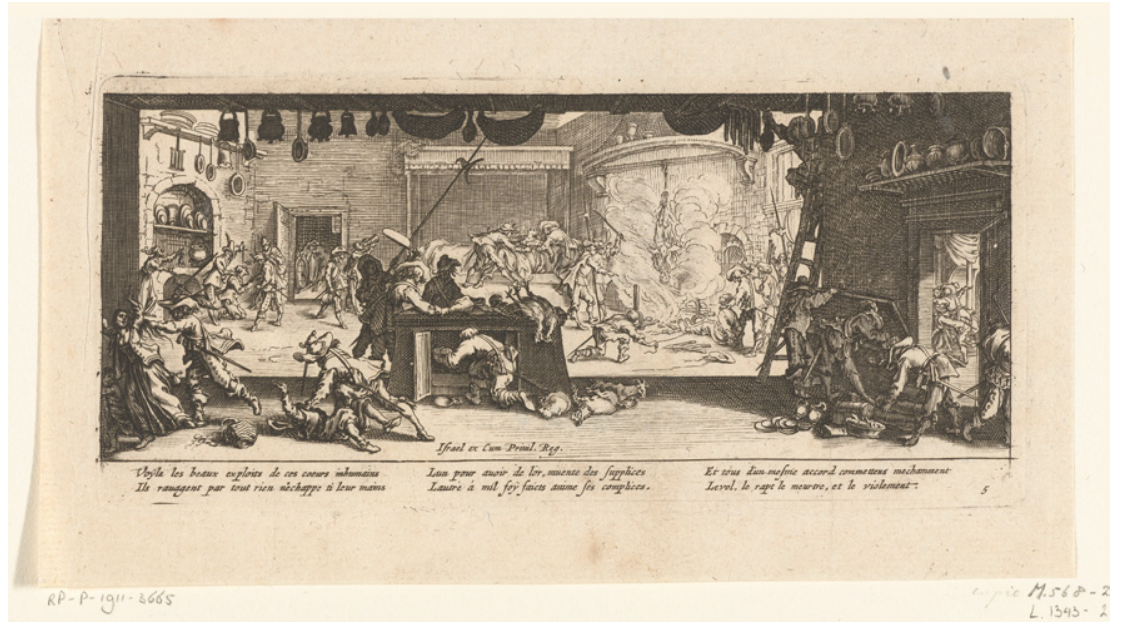

Fig. 4: Jacques Callot, Les Grandes Misères et Malheurs de la Guerre (1633). Rijksmuseum Amsterdam, RP-P-1911-3665.

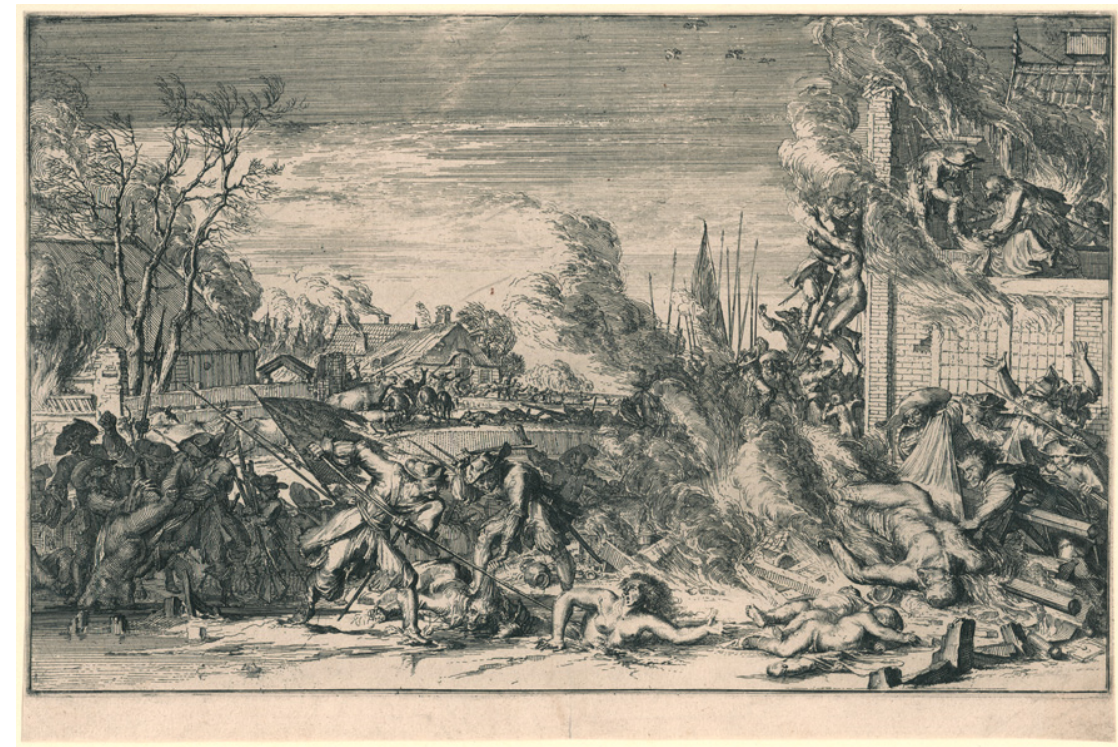

Fig. 5: Romeyn de Hooghe, French Cruelties in Dutch Villages, 1672 (1673). Rijksmuseum Amsterdam, RP-P-OB-77.197.

seventeenth century, the Dutch Republic had developed into the cultural hub for the Republic of Letters and had established itself as le Magazin de l'Univers (an universal warehouse): the export centre for 


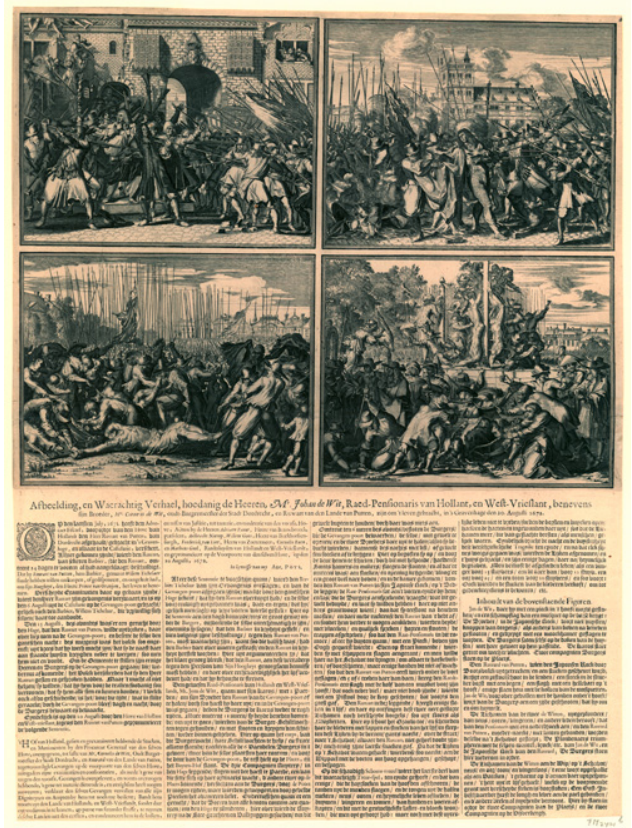

Fig. 6: Romeyn de Hooghe, Afbeelding, en Waerachtig Verhael, hoedanig de Heeren, Mr. Johan de Wit ... benevens sijn Broeder ... zijn om 't leven gebracht (Depiction and true story of the [...] deaths of Johan and Cornelis de Witt) (1672). Rijksmuseum Amsterdam, RP-P-OB-77.136.

a considerable part of the European market for texts and images. ${ }^{8}$ The Dutch knowledge economy (the first knowledge economy of Europe $)^{9}$ not only filled the European book market with printed texts but also, propelled by an advanced creative industry of printers, artists, engravers and map-makers, helped to develop an extensive market for prints and illustrated books. ${ }^{10}$ During the seventeenth century, the Calvinist republic slackened its religious hesitance towards images and embraced the visual, even printing illustrated Bibles and catering to the new market for such Bibles. ${ }^{11}$ Images were everywhere. It is estimated that during the Golden Age of the Dutch Republic, no fewer than five million paintings were produced. Most Dutch households had paintings or other kinds of imagery hanging on their walls. ${ }^{12}$ Although the rise of this new visual culture of knowledge has been studied in depth, ${ }^{13}$ few studies have researched imagination techniques through a cross-media perspective with the aim of understanding the impact of these webs of images on the early modern viewer. ${ }^{14}$ 


\section{Cultural History}

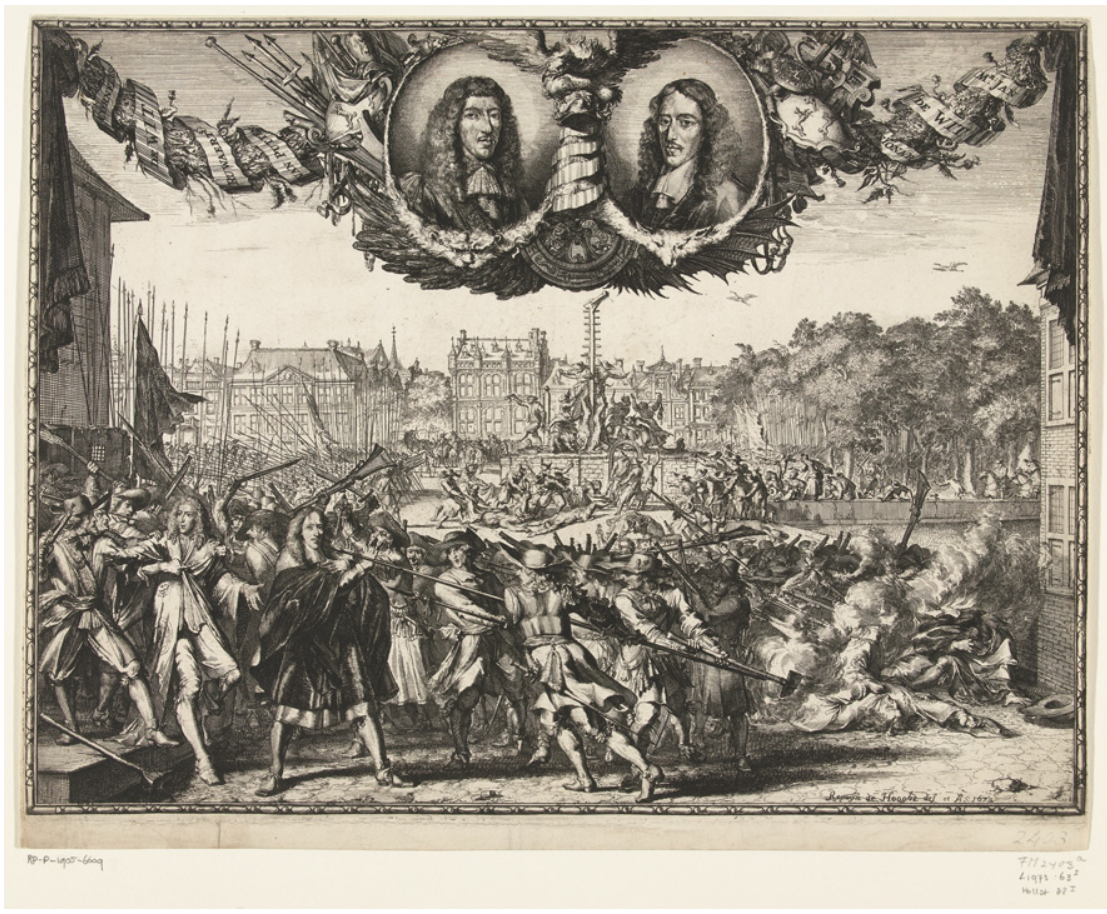

Fig. 7: Romeyn de Hooghe, Murder of the de Witt brothers (1672). Rijksmuseum Amsterdam, RP-P-1905-6609.

Immediately after the gruesome slaughter of the de Witts in 1672, the atelier of de Hooghe started to put out broadsheets which covered the event, with changing combinations of scaffold scenes, crowd action, tableaux vivants, portraits and texts (Figs 6 and 7 ). The de Hooghe prints were copied frantically, transformed and reprinted, often anonymously, but also by famous artists like Jan Luyken and Bernard Picart. ${ }^{15}$

De Hooghe's prints remained popular until the end of the eighteenth century. People could buy the series of prints, separate scenes taken from them, or other combinations, with or without textual explanations. All sorts of re-mediations took place. The painting by de Baen (Fig. 2), for instance, was copied and turned into print. Coins were minted, some after a design by de Hooghe, with the portraits of the brothers on one side and the scaffold, two sinking ships or a man-devouring monster on the other (Fig. 8). These coins were themselves put into print: they were represented on broadsheets and included in illustrated books (Fig. 9). The many visual and textual stagings of the slaughter thus allowed the public to relive and absorb the events from every 


\section{Imagineering}
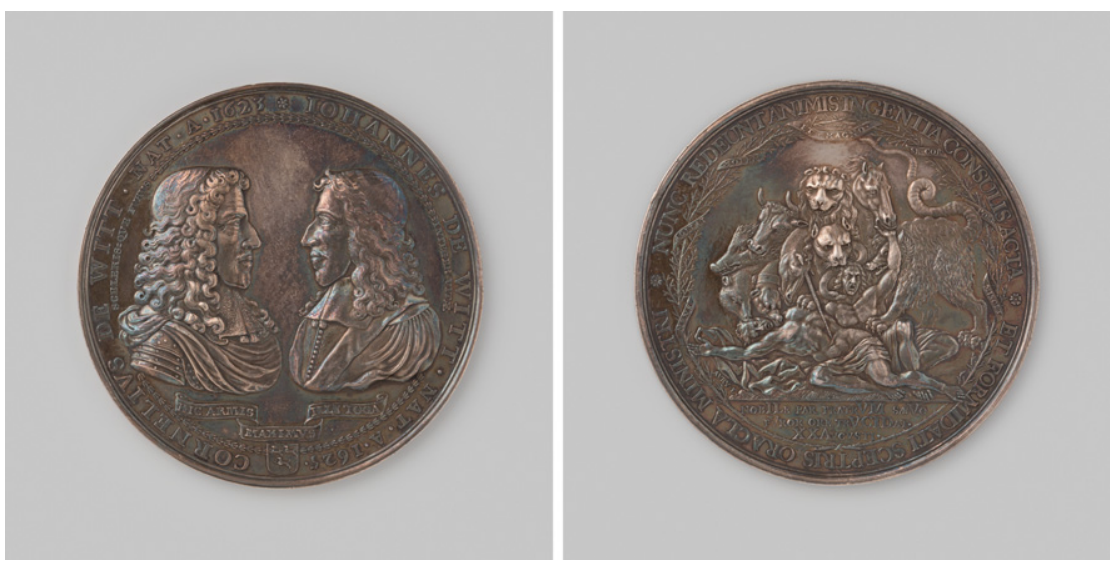

Fig. 8: One of the silver coins on the de Witt murders. Design by Romeyn de Hooghe, minted by Pierre Audrey. Rijksmuseum Amsterdam, NG-2014-3-1.

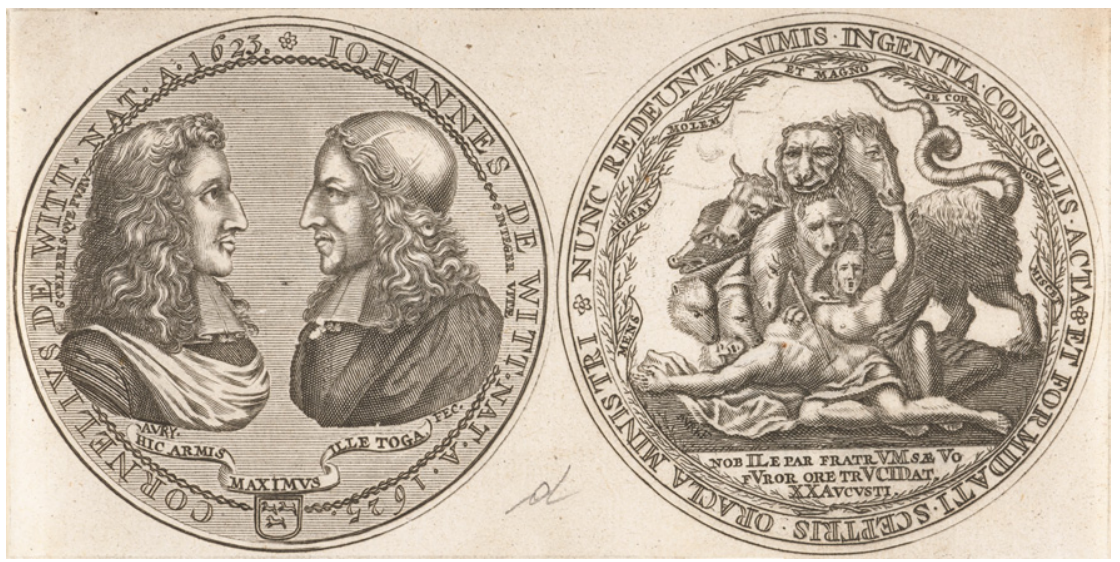

Fig. 9: Engraving of one of the silver coins minted in memorization of the de Witt murders. Rijksmuseum Amsterdam, RP-P-OB-82.250.

possible angle and perspective by reading, watching and, in the case of coins, touching.

All these images deploy different cultural techniques of representation. This diversity shows that de Hooghe's work was clearly informed by the booming art market of the Dutch Golden Age, in which violence was a major theme, for instance in engravings of the gruesome deaths of saints and martyrs. ${ }^{16}$ The de Witts are similarly presented as helpless but dignified men, seemingly untouched by the mass of violent energy that is released on them. Here the images are part of an explosion of prints 
and printed violence, of which de Hooghe himself was one of the central producers. While Dutch paintings predominantly presented more peaceful scenes (landscapes, still lifes, interiors, portraits), the print industry seems to have grown more violent as time went on. That is, an impressive amount of the Dutch print market concerned the visual staging of violence. Engravers and print houses produced new modes of imagining atrocities, with depictions of public executions, sea battles, martyr stories, torture handbooks, battlefield scenes, horrifying Old Testament stories, exotic tyrannical 'justice', beheadings, rapes, pillaging, iconoclasm, furies, raids, shootings, stabbings, piracy and looting - in short, every form of violence imaginable. ${ }^{17}$ For instance, de Hooghe's workshop produced over 3,500 prints, of which an amazingly large number are extremely violent. ${ }^{18}$ The at times gigantic violent scenes (which could be used as wallpaper through a combination of various folios) offer explosions of bodies and 'tronies' (faces affected by extreme passions), seemingly disordered. They invite the viewer to constantly re-engage with the clustered scenes, the various storylines and the explosion of bodies represented in agony. ${ }^{19}$

One of de Hooghe's specialities consisted of visual news reports on war events and political cartoons. In 1672, before de Hooghe designed his etchings of the murder of the de Witts, he made visual reports of the looting, pillaging and raping by the French army in the villages of Bodegraven and Zwammerdam (Fig. 5). Here de Hooghe confronts his audience with images of soldiers throwing babies in the fire, raping or hanging villagers and committing other cruelties similar to those in Callot's depiction of soldiers pillaging villages during the Thirty Years' War (Fig. 4). The title, Franse wreedheden (French cruelties), is revealing as it evokes the 'Spanish tyranny' or 'Spanish atrocities' which had been meticulously catalogued and printed by the Dutch. The prints also refer back to the French atrocities of Saint Bartholomew's Day in 1572, which had caused an outcry in print (Fig. 10).$^{20}$ De Hooghe's horror scenes thus fell into a rich visual culture of printed stagings of violence.

Evoking these contexts helps us underline an important shift. While we have only a handful of visual representations of the slaughter of the French Huguenots on Saint Bartholomew's Day, we have hundreds of visual depictions of the 1672 crisis.

In this context, it is telling that Willem Baudartius, in his Morghen-wecker der vrye Nederlantsche Provintien (Wake-up call for the Free Dutch Provinces) (1610), found it necessary to explain why he presents a long list of 'atrocities, murders, arsons, pillaging, destruction, and other forms of violence': he esteemed it necessary to 'in te prenten' (to print or impress) these events in the minds of youngsters, so that they would 


\section{Imagineering}

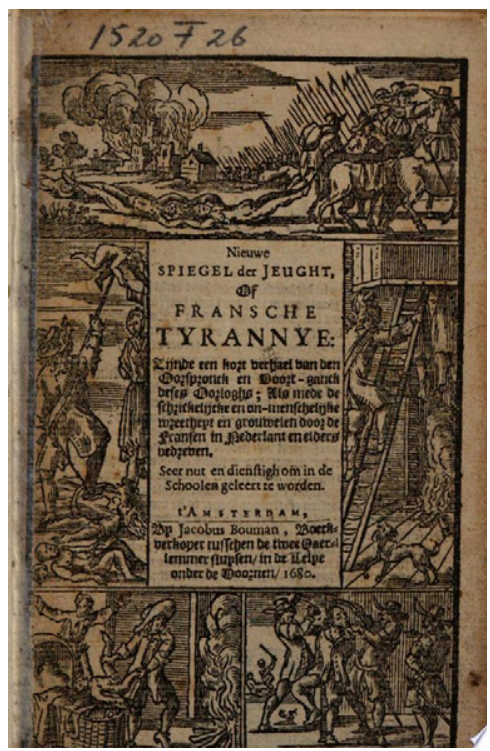

Fig. 10: Title page of the Nieuwe Spiegel der jeught, of Fransche Tyrannye (New Mirror for Youngsters, or the French Tyranny) (1680). Universiteit van Amsterdam, Allard Pierson, OK 62-8586.

never be forgotten. ${ }^{21}$ This technique of imprinting highlights the shift from a more textual to a more dominantly visual strategy during the seventeenth century. Yet there is more to this shift in the print industry than the mere quantity of images. The imagery also became more graphic, in the figurative sense of the word, and realized a shift from a theatrical to a spectacular regime.

\section{The theatrical and spectacular regimes}

The transition from a theatrical to a spectacular regime can be explained through a comparison of the de Hooghe and the Callot prints. The Callot prints were distinct forms of early modern re-mediation; ${ }^{22}$ that is, the etchings followed the logic of the theatre. For instance, one of the best-known Callot prints depicts the violent acts that took place during the plundering of a farm. The text underneath the image frames these acts as follows:

Here are the fine exploits of these inhuman hearts / They ravage all over, nothing escapes their hands / One invents forms of torture to get some gold, / The other, having committed 1,000 crimes, encourages his accomplices / And all in accord, they maliciously commit / Theft, kidnapping, murder, and rape. ${ }^{23}$ 
Formally speaking, the text underneath the image prefigures a form of comics in later centuries but also hints at two other genres that were popular at the time. Firstly, the interaction between text and image is comparable to the way in which emblems were supported by text. Owing to its ironic tone, however, the text also clearly embodies a distinct speaker, a voice. Text and image combine in a way that resembles theatrical tableaux, which were almost always accompanied by an explanatory text or an actor explaining what people were seeing. Moreover, the image is re-mediated formally in a theatrical way. This formal re-mediation is due to the clear-cut dark frame, the perspective, the use of light and the form of the textual 'plinth' at the bottom. Taken together, these things suggest we are looking at a stage.

Callot is reported to have invented a new etching needle called the echoppé and was especially inventive in techniques of lighting that created depth in his prints. ${ }^{24}$ This way of creating depth in prints relates to the ways in which depth was suggested in paintings, but, again, the depth also suggests a stage. In Figure 4 the use of light and shadow effectively divides the space into a front stage and a backstage area, with coulisses from which the actors enter and leave. The textual plinth that forms the step up to the stage demands that the audience asks what its relationship to the scene depicted is. Theatre techniques are being transplanted, then, to the realm of print, as a result of which key aspects of theatricality come to position the viewer in relation to actors who are now brought to act out something that provokes reflection. Secondly, readers/viewers are changed into an audience that is related to, or required to reflect on this staged action - that is, action performed on a stage. As a result, through the relationship that is brought into play, both actors and audience are made to question what they think and feel to be the very acts they are participating in.

Now compare Callot's etching to the de Hooghe prints (Fig. 11). It is not possible to reprint the image adequately, but one can view it on the website of the Rijksmuseum; by zooming in and out, the reader may experience how the image does not aim to put things at a theatrical distance but rather to draw the viewer in to examine one gory detail after another.

The print is exemplary here for how in the course of the seventeenth century, the printing industry became a powerful centre that worked through a spectacular dynamic but one different from the familiar spectacle that had had the king, or any sovereign power, as its centre. The spectacular was the result of a commercial network that produced a proliferation of images. This kind of spectacle did not subject people to some sort of mysterious royal power but drew them into an artificially 


\section{Imagineering}

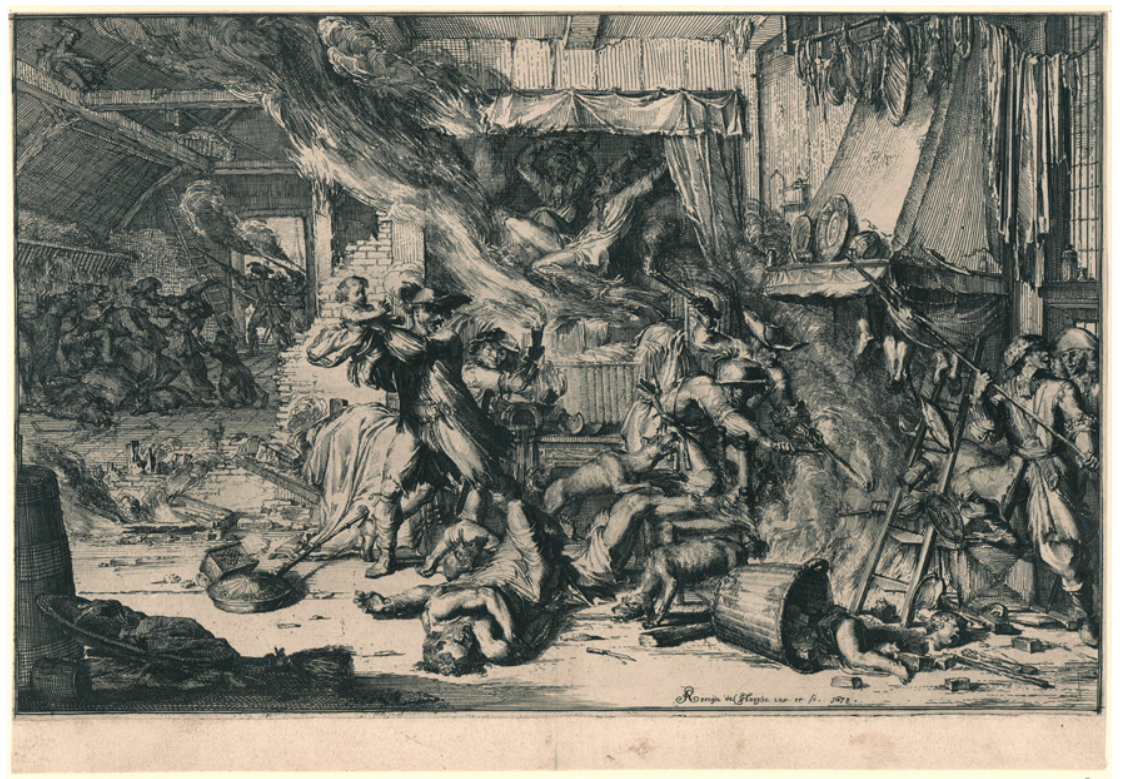

Fig. 11: Romeyn de Hooghe, French Cruelties in Dutch Villages, 1672 (1673).

Rijksmuseum Amsterdam, RP-P-OB-77.195.

construed world that provoked acts of involvement in addressing all the senses. Much more than Callot's theatrical scenery, de Hooghe's work makes one hear the cries of children and the grunts of slaughtered pigs, feel the heat of ignited fires and smell the odour of roasting human flesh.

The differences between the two images help us to distinguish the theatrical from the spectacular. Theatricality is a form of controlled representation, profoundly rhetorical and hence political, a technique through which the powers that can be control their citizens by centralizing their gaze and transforming them into a controllable mass. Moreover, theatricality stimulates political reflection as it invites the spectators to engage in reflection and develop an alternative perspective on their reality. It also stimulates the spectators to take pleasure in imagining other possible worlds (one could argue that this is Callot's position). Theatricality's core strategy is dramatizing, which we understand here as representing reality as a narrative fiction and hence inviting the spectators to observe their own reality from a distance, as if it were a coherent, controllable entity. ${ }^{25}$

Spectacle, in contrast, is intrinsically linked to public events organized by absolutist rulers or ruling powers. Further, we argue, the spectacular 
was propelled by a new system of pre-capitalist commercialization and circulation. Rather than influencing and hence politicizing public space, the spectacular explored the curiosity and the desires of a new early modern public of consumers and sought to tap into and trigger a passion for awe, horror, hard knocks and intense experiences. It did not aim at organizing perspective (positioning the individual spectator in relation to a larger entity) but rather prioritized collective and individual experiences. Through a hyperbolical system of representation, in which narration was replaced by a juxtaposition or rather a swirl of images and actions, the spectacular turned the spectator into a voyeuristic consumer enjoying experiences which were at times ordered by ruling powers but were also in part profoundly out of governmental control. This particular mechanism did not imply the absence of control; rather, it was sheer power hiding itself, or selling itself as an enjoyable or at least interesting private experience.

\section{Imagineering, material infrastructure and the self}

Marshall McLuhan considered the Renaissance revolution in the print industry as a matter of societal centralization. Whereas this centralization was at first inclusive, captured in the king's body, it changed to become exclusive, involving different specializations, functions, areas and individuals. ${ }^{26}$ The Callot and de Hooghe sets of etchings partly confirm but also contradict McLuhan's argument. Callot was working with royal licence and in that sense depended on a monarchical or princely centre. Yet his relationship with Louis XIII was remarkably oppositional. When, in 1633, he was asked to depict the celebration of the taking of Nancy by Louis XIII, he refused. His commitment to and feelings for his hometown in Lorraine were too strong, as was his revulsion about what had befallen the region during the Thirty Years' War, in which Louis had played a decisive part. Yet the later reprints of his work were not related to any specific power centre at all. They were part and parcel of a new industry and a vast market. And with the arrival of the spectacular circulation of images, the domain of the visual 'stepped up to high intensity' and started to act 'as an anesthetic for other senses', as McLuhan phrased it. ${ }^{27}$

A new system of techniques of the imagination developed, then, in the context of the rapidly expanding cultural market for books, maps, art, news, theatre and other kinds of sociability, resulting in a new public realm for the production, design, consumption and consolidation of images. The scale of the cultural industry that materialized in the course of the seventeenth century gave rise to a form of power that depended on distinct forms of engineering. Images - not just sets of them but entire 


\section{Imagineering}

networks of them - came to form a major sector of cultural engineering. Imagineering describes this historical shift, in which new techniques were deployed to make images speak to the public and to one another, thereby technically construing specific forms of individual and collective selves, the entire infrastructure by means of which people not only were staging themselves but also found themselves embodied in, and encircled by, a network of images and imaginations.

Over the seventeenth century, then, a material infrastructure developed that embedded all printed images in a web that was both theatrical and spectacular. This material infrastructure consisted, first of all, in a transnational, European-wide (and later even global) network of the production and consumption of images, a network in which each node could be connected to another node within the infrastructure. Secondly, it involved techniques that, although developed in one medium, could easily travel to others, as when paintings were turned into engravings, or prints formed the basis of tableaux vivants, or the logic of the theatre was transported into portable miniature theatres by travelling showmen. Thirdly, it consisted in the embedding of different media and different techniques in one another, as when spectacle could easily embed theatrical scenes, or when etchings or maps would appear in paintings, or paintings in etchings. All in all, this material infrastructure came to redefine the way in which subjects understood themselves in a theatrical or a spectacular way, which in both cases implies an embodied way. The concept of imagineering is not restricted to the visual but connotes techniques, bodies, machines and all sorts of artefacts at work, involving all the senses and propelling various forms of imagination.

Conceptually speaking, imagineering is a portmanteau of imagining and engineering. Johannes Suitner traces the term's origin back to an advertisement from 1942 by ALCOA, the Aluminum Company of America, in Time magazine, stating, 'Imagineering is letting your imagination soar, and then engineering it down to earth. ${ }^{28}$ In a sense, this is how Suitner uses the term, relating it to imaging, which he defines as a strategic use of images to represent urban environments. He then considers imagineering as a process in urban development "where discursive meaningmaking functions as a legitimation and stabilization of certain material practices in planning ${ }^{29}$ In other words, in the field of urban studies, imagineering refers to the translation of imaginary representations of an environment into material reality. The second context in which imagineering is used in urban studies is postmodern architecture. Scholars may speak, for instance, about the ways in which people are 'guided by the large amount of vivid information and story lines put in place 
by Disney imagineers' ${ }^{30}$ A straightforward definition would be 'the conscious creation of places with characteristics similar to other places (as in Disneyland). Often seen as the creation of a superficial veneer or façade of culture. ${ }^{31}$ Our definition expands on this double use of the term but also works the other way around. We consider how the material production of images constitutes not so much a decoration or a mode of appearance but a collective cultural imagination, as a cultural technique that produces distinct historical selves.

As for these selves, Katie Hornstein found it remarkable that in Callot's set of prints, published in the midst of the Thirty Years' War, what took precedence was

not a polemic in favor of a particular nation, religion, or class. Rather, there is an insistent focus on the relationships that diverse groups of people have toward the violence that accompanies war: those who endure it, those who observe it, and those who actively partake in it. ${ }^{32}$

If these prints did not address people so much for the particular situation in which they found themselves (nation, religion, class), this was due to their generic theatrical form. War was not represented in its particular context but was restaged through the format of the images. This format allowed violent acts of war to be played out again, on this imaginary stage, with people acting - acting upon others and an audience. Thus, the prints were not so much to be looked at, although this was part of the experience. Rather than constituting mere objects for viewing, they invited forms of dramatic re-enactment. This was strengthened by the clear plot in the set of prints, which started with the recruitment of troops, followed by the battles, the horrors of war, the punishment of deserters, the aftermath and the glorious return with each individual print being analogous to both a scene and a dramatic act.

In contrast, de Hooghe's etchings relate to another form of self. Here the issue is not theatrical or dramatic re-enactment but, in a sense, the loss of self, because the reader/viewer is swallowed up by the image in fascination, lust, disgust and horror. The public nature of theatre is accompanied by a visual domain that manifests itself in the privacy of homes, even if books and etchings might be shown to company or would be the topic of debates and conversations. That is, to consider the images of violence as the object of a voyeuristic eye only would be putting it wrongly. Rather, through their eyes the viewers have lost their selves by being taken up in the swirl of images. ${ }^{33}$

As a gerund that can also be used to form a continuous tense, imagineering emphasizes that it is continuously at work, both externally 


\section{Imagineering}

and internally, in what people see publicly and what they see in their imagination, both in terms of machineries and in terms of behaviour. Thus, the making, reproduction and consumption of images are not about reality, or not only. They articulate the real. ${ }^{34}$ The cultural techniques implied by imagineering are aimed at involving the onlookers in a more sustained, embodied way, inviting them to take private pleasure in the images, which in turn would allow them to metaphorically disappear into the depicted reality.

As the preceding examples may indicate, we unpack imagineering in terms of formal media techniques (those of painting, etching, printing, theatre-making, etc.) and societal techniques, aimed at construing not just individual selves but collective ones, in the sense that Foucault defined them, as 'technologies of the self..$^{35}$ Imagineering thus

- implies a matter of representation that works performatively and is constitutive of reality;

- does not concern a process engineered by controlling powers but is the result of a complex interaction between actors and media, which together result in new conceptions of reality;

- lays on individual and collective imaginations while being propelled by them; and

- involves readers or viewers by taking them up in a circulation of images that influence how they find themselves in the world as selves.

In the reception of Stephen Greenblatt's groundbreaking study on the technical construction of the early modern self, Renaissance SelfFashioning (1980), the major source of influence for this study, namely the work of Foucault, got a bit lost. ${ }^{36}$ The term self-fashioningindicated the conscious self-presentation of players in a cultural market. The self had become a Homo economicus. Yet Foucault claimed that selves cannot make themselves and are not rational and economic players in a market; that would be a deceptive fiction of the self. For Foucault, human selves are fundamentally made in a complex and dynamic field of practices and discourses. The self is not a natural given with a rational centre; it is moulded, fashioned into being, in a force field that is characterized as much by irrational or libidinal economies as by rational ones, which all stand in the service of powers or are charged with powers themselves. In our final section, we focus in more detail on this material entanglement in terms of an economy that formed the nexus of political and commercial powers in the Dutch Republic. 


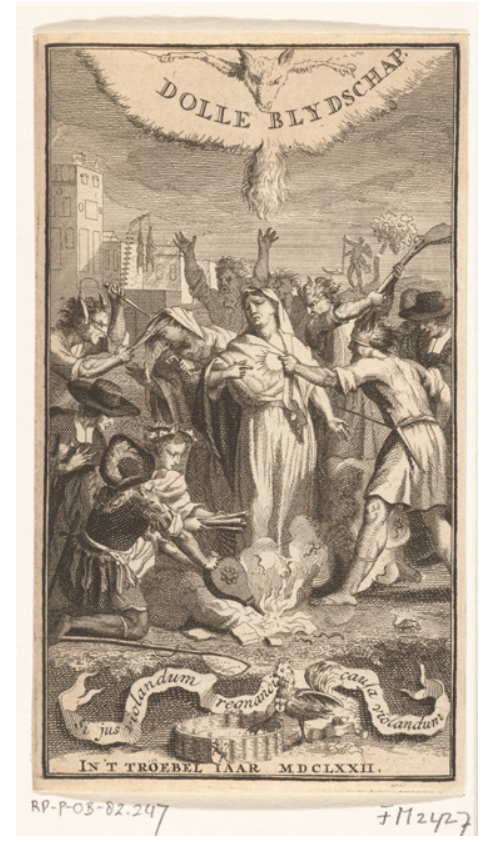

Fig. 12: Engraved frontispiece for J. Oudaen's play Haagsche broeder-moord, of Dolle blydschap. Rijksmuseum Amsterdam RP-P-OB-82.247.

The political and the commercial: Anatomy and the theatre of horrors The increasing coexistence of theatricality and the spectacular in the seventeenth century cannot be separated from a new conception of power, from sovereignty and forms of gouvernementalité, on the one hand, and new forms of power embodied in the market, on the other. Both aimed at discipline by means of theatrical techniques or the internalization of power through spectacle, with the abundance of visual material functioning as the primary lever for this new visual culture. In the network of printed works, images were to be seen and reseen, shared in individual and communal circles in order to be done and internalized, fuelling forms of imagination. They needed to be dealt with in a performative sense, in the double sense of that term: they were a matter of performance and of performativity. Let us return to the murder of the brothers de Witt in 1672 to explain this.

One of the eyewitnesses of the 1672 event was the Rotterdam poet Joachim Oudaen (1628-92), who worked his report of the events into a theatre play, The Hague's Brother Murder, or Insane Joy (Fig. 12). ${ }^{37}$ The report, a manuscript labelled by Oudaen as 'memories of an ear and eye witness', ${ }^{38}$ presents a horrifically detailed description of 


\section{Imagineering}

the events: how the brothers were forced to exit the prison into the open square, where the angry mob stabbed, beat and shot them to death and how the corpses were mutilated and the parts sold as memorabilia:

Now the corpses had to suffer. Someone cut the fingers off the hands, another the noses off the faces, the lips off the mouth, the ears off the heads, the tongues from the mouth, the toes off the feet, and everything was then sold to the bystanders, one item cheaper, another more expensively ... As the trade in fingers, toes, noses, ears, lips, etcetera, went ahead spectacularly, the private parts were not spared: everything else was sold out. ${ }^{39}$

The brothers' corpses became merchandise, curiosities. Small pieces of their clothes were sold 'to whoever showed interest. Bloody cloth was the most expensive.' Then Oudaen reports, 'On my way home I bought the index finger of Mr Johan De Witt for two shillings and a little old jug, and three stivers for the brandy in which the finger had been preserved during the night. ${ }^{, 40}$ So before there were actual representations of this specific historical event on the market, the sinister remnants of the event were immediately sold as commodities on a market, provoking frenzy, curiosity and horror. Even Oudaen himself, although disgusted by what he had witnessed, could not distance himself from the marketing of the dissected bodies.

Oudaen's report can be read as an event of imagineering at the intersection of various visual traditions, not just circulating prints with representations of public executions but also the theatre of horrors and the practice of anatomy. In the Dutch Republic, a growing number of anatomical theatres, anatomical cabinets and books of anatomy employed theatrical techniques, but these also reveal how the spectacular had increasingly infiltrated these modes of representation. The English painter Thomas Person, who visited the anatomical theatre in Leiden in 1687 , strikingly describes it as 'a theatre of horrors' ${ }^{41}$ In the theatre, the spectators are invited to combine their exegetic look (looking for explanations) with a divulging look (looking for experiences). In terms of experience, anatomy became part of a market; in Amsterdam one could buy a ticket to attend an anatomical lesson for six or seven pennies. ${ }^{42}$ From 1587 onwards, public dissections were held in the former chapel of the Saint Margaretha convent, where the anatomists shared a floor with the chamber of rhetoric called 'In liefde bloeyende' ('In love we flower'). By the end of the century, the building was too dilapidated to cope with the big public interest, so the anatomical lesson moved back to the Saint Anthony weighing house. ${ }^{43}$ 
This Theatrum Anatomicum (the snijburg; literally, 'the cutting castle') had room for 500 spectators, with a revolving table in the middle for maximum visibility; 'several lights in the roof shine directly on the cutting table'. ${ }^{44}$ The anatomical theatre was 'a cultural centre where pleasure, culture, excitement, instruction and entertainment met'. ${ }^{45}$ Here the same commercial laws applied as in the playhouse: 'The success of anatomy, just like any other theatrical performance, depended largely on the size and on the sympathetic response of its audience. ${ }^{46}$ Not clinical distance but immersion was central to what Jonathan Sawday called 'the spectacular culture of dissection'. Along with the anatomical lesson, sumptuous dinners were often organized, accompanied by music. ${ }^{48}$ Public dissections also related to the judicial system, as they mostly used corpses from executed criminals. Making the bodies that were cut open analogous to those who were executed served the sovereign power, as Sawday argued. ${ }^{49}$ As such, the theatrical event called the anatomical lesson brought together three forms of spectacle: execution, public dissection and semi-public banquet. ${ }^{50}$

A comparable combination of the theatrical and the spectacular can be found in anatomical cabinets. In the famous cabinet of the Amsterdam anatomist Frederik Ruysch, preparations become true mise-en-scènes. Ruysch succeeded, in his own words, in 'render[ing] deceased bodies in such a natural way, so that they cannot be discerned from a living and sleeping human being, all limbs, that are motionless in deceased people, nearly moving as in a living human being. ${ }^{51}$ In these cabinets, the experience itself, the beholding and the sensation of looking, became merchandise. Moreover, Ruysch's anatomical preparations and his dioramas of fetal skeletons (displayed in landscapes of embalmed human organs) were also marketed as prints in publications of his work (Fig. 13).

The prints of Ruysch's anatomical tableaux vivants present a third layer of the anatomical spectacular: the anatomical atlas. One of the most famous Dutch atlases, the Anatomia Humana Corporis (1685), was written by Govert Bidloo, a former pupil and later adversary of Ruysch who was the court physician of William III. ${ }^{52}$ His anatomical atlas, with drawings by Gerard de Lairesse, offers a spectacle of bodies, laid open for the spectator as true mise-en-scènes (Fig. 14). Bidloo was a clever marketer who perfectly understood the growing market for spectacle and used his atlas to turn anatomy into an individualized experience. His atlas was his calling card: it had to advance his career as a medical professor and function within an economy of affects at the same time. ${ }^{53}$ The spectator gets the illusion of being in the anatomist's seat, seeing all the details of the dissection almost as if in real life. Bidloo uses ropes, nails and other 


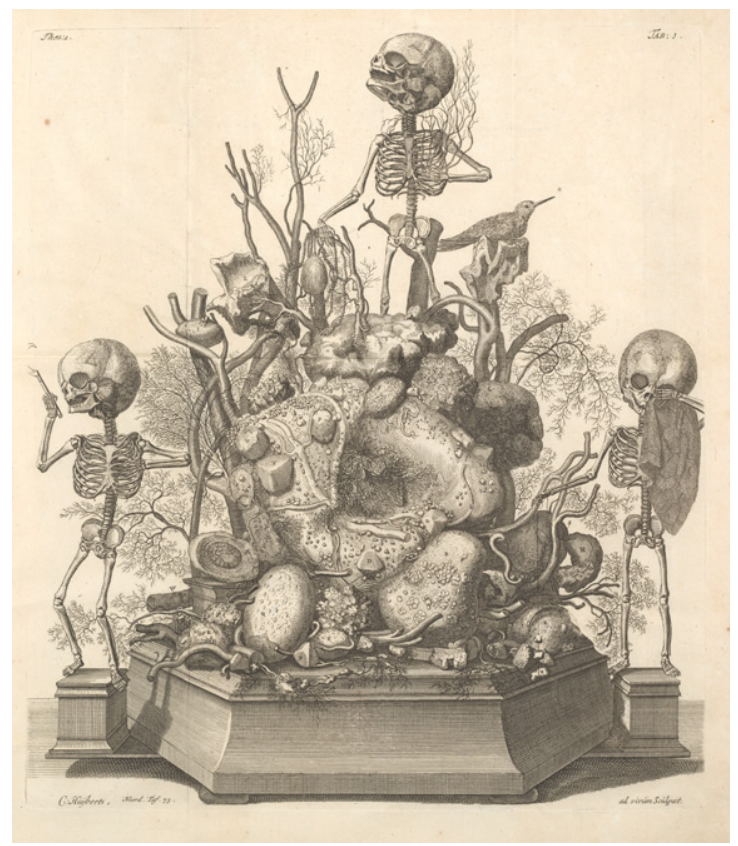

Fig. 13: Illustration from Frederik Ruysch, Alle de ontleed- genees- en heelkundige werken, vol. 2 (1744). Ghent University Library.

supporting parts to stage-manage the body as well as possible, as if the corpse is placed in a mise-en-scène, laid open for the spectator by a skilful metteur-en-scène. It is no coincidence that de Lairesse in his drawings clearly shows that you are looking at particular bodies. We see hair and other physical details (all but the face) that remind the spectator that the represented parts originate from a specific body, a specific life. The body that is laid open becomes a potential mirror of the body of the spectator.

Bidloo probably learned his techniques of display from the theatre. Not only did he write several plays, he also was active in poetical debates and became an opponent of the famous and influential classicist art society Nil Volentibus Arduum (founded in 1669). Between 1684 and 1688 , he had close contacts with the two managers of the Amsterdam theatre. ${ }^{54}$ Although Dutch theatre has traditionally been labelled as classicist, averse to the spectacular 'Catholic' baroque, this view is currently under revision. ${ }^{55}$ The case of Bidloo also indicates that when it comes to violence and the spectacle of the body, the boundaries between classicism and the baroque were blurred. ${ }^{56}$ Moreover, in the Dutch 


\section{Cultural History}

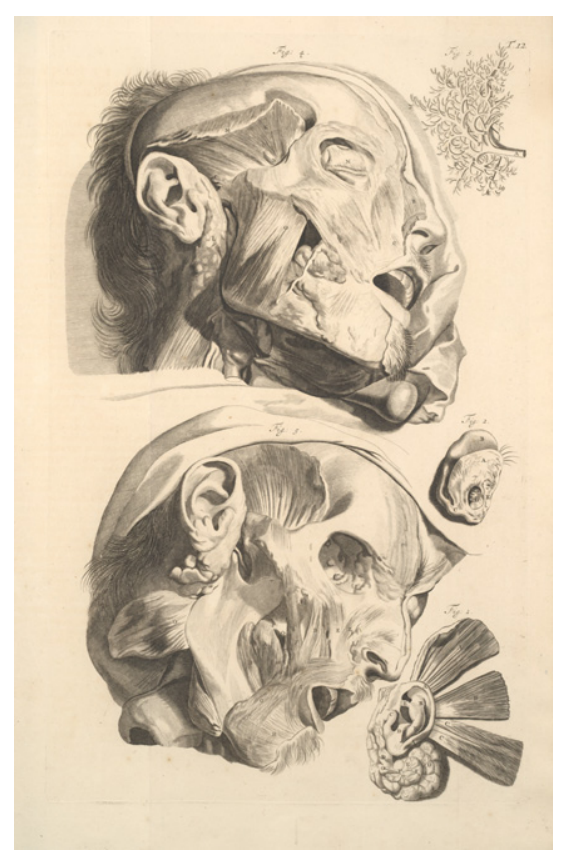

Fig. 14: Govert Bidloo, Ontleding des menschelyken lichaams (1690). Engraving by Gérard de Lairesse. Ghent University Library.

Republic, the introduction of the Senecan horror tragedy increased the staging of violent scenes. Around 1600, symbolically violated corpses started to haunt the repertoire. ${ }^{57}$ These Senecan tragedies are characterized by a set of basic ingredients: highly placed figures, rhetorical language and a large dose of gruesome events with an unhappy ending. Abundance (copia) and variety (varietas) are the most important dramaturgic principles in the development of the play, which uses an episodic sequence of loose building blocks rather than a tight plot. In many of these plays, the body - whole, wounded or opened up - is centre stage, most famously in the repertoire of glassmaker and poet Jan Vos. ${ }^{58}$

We have only an incomplete idea of how horrors were engineered onstage. In many European theatres, the striking effects of the latemedieval mystery plays, fake blood, prostheses, pyrotechnics, were still used in the seventeenth century. ${ }^{59}$ Within the new theatrical architecture and machinery, these techniques could gain new effect and be reinforced by new inventions. ${ }^{60}$ In Vos's plays, many scenes demanded that the physical violence be shown, like in Aran en Titus (Aran and Titus): the dangling corpse of Bassanius, two crushed dead bodies in a 


\section{Imagineering}

pit, Titus cutting off his own hand, the heads of two brothers being brought in, and, as a prologue to the final horror, the fifth scene of the fourth act when Titus cuts his enemies' throats, asking Rozelyna to collect their blood in a dish and then, realizing she has no hands, asking her to tear their hearts from their bodies with her teeth and to spit in their faces. ${ }^{61}$

Baroque plays depicting gory violence both verbally and visually, such as the revenge tragedies by Vos, aimed to immerse the spectator in an embodied frenzy of awe and horror and thus gave ample room to the individual experience of the spectators, who were invited to leave behind their disbelief and eagerly enjoy the gruesome details of the depicted scene, shivering with horror and enthusiasm, often simultaneously. Vos's theatre is not about controlling or centralizing the gaze of the spectator in the service of power, that is, ensuring that all spectators experience the play in a similar way. On the contrary, his plays embrace the baroque spectacle by prioritizing the individual experience of each spectator, as Vos knew how to position himself perfectly in the rapidly expanding market for spectacular representation of bodies and violence.

The performative effect of tragedies such as those of Vos - the impact on spectators and their surrounding realities - cannot be separated from the staging of violence outside the theatre. Both were fundamentally intertwined, constantly influencing one another. That part of the public saw opened-up bodies with their own eyes, in real life or via prints, made an embodied experience of theatrical violence possible. What Sawday termed the "culture of dissection" ${ }^{62}$ functioned as a structuring regime that framed how horror was actually experienced physically in the theatre, even if the mode of representation was evidently artificial and therefore implausible, also for the spectator at that time. With the imagineering power of plays like Aran en Titus in mind, we might hypothesize about their effect on the lynching of the de Witt brothers. Was this a spontaneous, uncontrolled outburst of violence, or was it (also) a scripted play, informed by the imagineering techniques in which the public was already being trained several decades before 1672 ?

\section{Conclusion}

In this article we introduced the conceptual term imagineering in the field of early modern studies to understand the fundamental shift that took place in the early modern period through the development of an advanced material infrastructure for the production, distribution, consumption and appropriation of images. It underlines the importance of techniques: the techniques of creation but also of seeing and of the self. The term imagineering can help overcome traditionally drawn 


\section{Cultural History}

boundaries between genres, media and modes of representation, such as classicism and the baroque, but also between national cultures, political systems and ideologies. By researching images across media, we are able to analyse how images speak to one another and to an audience, how the theatrical and the spectacular may intersect and how, through embodied and sensory experiences, imaging may help to craft new selves and realities.

In each of the cultural objects we have analysed, embodied experience is central. The theatre plays, the executions, the prints and the anatomical lessons and atlases all sought to involve the public physically and sensually. The techniques were deliberately overwhelming. The concept of imagineering allows us to describe the creation of a world in which reality was based on consumers' affective intertwinement with images. The early modern visual dynamic can thus be characterized as follows: the spectacular functioned thanks to the commodification of the human body and sensory experience. Producers needed to create new markets as well as serve an existing one, satisfying clients in their inquisitive search for knowledge and excitement. Yet the early modern image economy was also constructing and reinventing realities. Thus, the process of imagineering worked owing to its interaction with the cultural imagination of the moment. Imagineering is therefore not just a duplicate (doordruk) of the context, as a mere representation, but also an imprint (indruk). Imagineering literally impressed (inprenten): it performatively altered the imagination through the effective use of a new cultural infrastructure that enabled abundance and continuous repetition.

However, the idea of imagineering does not fit only the seventeenthcentury baroque circulation - or rather swirl - of images; it is also an interesting notion to rethink the performative potential of images and visual regimes in present-day culture. Let us, as a sort of theoretical encore, return to the case with which we started: the Brussels wall painting. The website of the artist who is most often suggested as the creator of such paintings, Vincent Glowinski (working under the pseudonym Bonom), shows how these gigantic wall paintings are made technically, in just one night, making use of ladders and ropes. ${ }^{63}$ Yet the peintures clandestines - veiled, covert, secret, furtive, and clandestine paintings - are also made to circulate in the 'urban representational space', as Henri Lefebvre called it. ${ }^{64}$ Indeed, the way in which this piece inscribed itself both in the urban environment and in the current acts of and debates on terrorist and military violence - of which Brussels has recently been the stage - is also a matter of technique: of how to make images speak to one another and to an audience. One telling feature is 


\section{Imagineering}

that no one has commissioned works like this, and the maker or author is as yet officially unknown. As a consequence, images appear as if phantasmagorically. Still, in and through their sudden appearance, the urban environment is changed, and because nobody saw the works being made, it is as if an actor has unexpectedly entered the stage. As a result, an audience is attracted, and a part of the city becomes a scene. Although immediately taken up in the swirls of internet images, which would fall under the rubric of the spectacular as we defined it, this piece can also be seen as a form of resistance to the spectacular in an attempt to retheatricalize public space, much as the works of Banksy are trying to do elsewhere. This illustrates that imagineering is not a totalizing concept. Rather, we use it as a heuristic tool that helps to historicize the specific forms of imagineering taking place and the different cultural techniques involved.

\section{ORCID}

Frans-Willem Korsten (1D https://orcid.org/0000-0002-9133-6807

Cornelis van der Haven (D) https://orcid.org/0000-0001-9708-5773

Inger Leemans (D) https://orcid.org/0000-0003-1640-4109

Karel Vanhaesebrouck (D) https://orcid.org/0000-0002-5471-838X

Yannice De Bruyn (D) https://orcid.org/0000-0002-6016-8783

\section{Notes}

1. Michel Foucault, Discipline and Punish: The Birth of the Prison, Alan Sheridan (transl.) (New York: Vintage, 1997), and Security, Territory, Population: Lectures at the College de France, 1977-1978 (New York: Picador, 2007).

2. Guy Debord's La société du spectacle (Paris: Champ, 1971) has a clear prefiguration in the Dutch print and theatre culture.

3. This article results from our research project 'Imagineering Violence: Techniques of Early Modern Performativity in the Northern and Southern Netherlands' (ITEMP), funded by the Dutch and Flemish Organisations of Scientific Research (NWO and FWO). The ITEMP project researches the theatrical or spectacular visualization of violence in different media in the seventeenth century. See our website: https://itempviolence.wordpress.com.

4. Henk van Nierop et al. (eds), Romeyn de Hooghe: De verbeelding van de late Gouden Eeuw (Zwolle: Waanders, 2008).

5. Luc Panhuysen, Rampjaar 1672: Hoe de Republiek aan de ondergang ontsnapte (Amsterdam: Atlas, 2009).

6. De droeve Ellendigheden van den Oorloogh: Seer aerdigh en konstigh Afgebeeldt door Iaques Callot. Loreijns Edelman. The Rijksmuseum (Amsterdam) and Metropolitan Museum of Art (New York) date the Dutch publication between 1670 and 1690. Most existing copies are of the eighteenth-century reprint by Leonard Schenk.

7. Hilliard T. Goldfarb, 'Callot and the Miseries of War: The Artist, his Intentions, and his Context', in Hilliard T. Goldfarb and Reva Wolf (eds), Fatal Consequences: Callot, 


\section{Cultural History}

Goya, and the Horrors of War (Hanover, NH: Hood Museum of Art, Dartmouth College, 1990), pp. 13-26.

8. John Michael Montias, Art and Auction in Amsterdam in the Seventeenth Century (Amsterdam: Amsterdam University Press, 2002); Neil De Marchi and Hans J. van Miegroet (eds), Mapping Markets for Paintings in Europe, 1450-1750 (Turnhout: Brepols, 2006); Karel Davids, The Rise and Decline of Dutch Technological Leadership: Technology, Economy and Culture in the Netherlands, 1350-1800 (Leiden: Brill, 2008); and Jonathan Israel, The Dutch Republic: Its Rise, Greatness and Fall, 1477-1806 (Oxford: Clarendon, 1995).

9. Jan Luijten van Zanden, The Long Road to the Industrial Revolution: The European Economy in a Global Perspective (Leiden: Brill, 2009).

10. Elmer Kolfin and Jaap van der Veen (eds), Gedrukt tot Amsterdam: Amsterdamse prentmakers en -uitgevers in de Gouden Eeuw (Zwolle: Waanders, 2011); and Clara Rasterhoff, The Fabric of Creativity in the Dutch Republic: Painting and Publishing as Cultural Industries, 1580-1800 (Amsterdam: Amsterdam University Press, 2017). Printed images also became an important aspect of the news press and of knowledge acquisition. Donald Haks, Vaderland en vrede, 1672-1713: Publiciteit over de Nederlandse Republiek in oorlog (Hilversum: Verloren, 2013).

11. Els Stronks, Negotiating Differences: Word, Image and Religion in the Dutch Republic (Leiden: Brill, 2011).

12. John Loughman and John Michael Montias (eds), Public and Private Spaces: Works of Art in Seventeenth-Century Dutch Houses (Zwolle: Waanders, 2000); Marten Jan Bok, Vraag en aanbod op de Nederlandse kunstmarkt, 1580-1700 (Utrecht: Utrecht University, 1994); and John Michael Montias, Artists and Artisans in Delft: A Socio-economic Study of the Seventeenth Century (Princeton, NJ: Princeton University Press, 1982).

13. Benjamin Schmidt, Inventing Exoticism: Geography, Globalism, and Europe's Early Modern World (Philadelphia: University of Pennsylvania Press, 2015); Lynn Hunt et al., The Book that Changed Europe: Picart and Bernard's 'Religious Ceremonies of the World' (Cambridge, MA: Belknap Press of Harvard University Press, 2010); Michiel van Groesen, The Representations of the Overseas World in the De Bry Collection of Voyages (1590-1634) (Leiden: Brill, 2008); and Susan Dackerman et al. (eds), Prints and the Pursuit of Knowledge in Early Modern Europe (Cambridge, MA: Harvard Art Museums, 2011).

14. The Disaster Year and the public outcry it generated have been studied from the perspectives of political and social history and the history of the press. Herbert H. Rowen, Johan de Witt, Grand Pensionary of Holland, 1625-1672 (Princeton, NJ: Princeton University Press, 1978); Rudolf Dekker, Holland in beroering: Oproeren in de 17de en 18e eeuw (Baarn: Ambo, 1982); Michel Reinders, Gedrukte Chaos: Populisme en moord in het Rampjaar 1672 (Amsterdam: Balans, 2010); and Ronald Prud'homme van Reine, Moordenaars van Jan de Witt, de zwartste bladzijde van de Gouden Eeuw (Amsterdam: Arbeiderspers, 2013). Meredith Hale describes the extensive news coverage of the events in popular prints as a 'bottom-up' process within the diverse, 'broad and dynamic market for images'. Meredith Hale, 'Political Martyrs and Popular Prints in the Netherlands in 1672: The Murders of Jan and Cornelis de Witt in the Early Modern Media', in Martin Gosman and Joop Koopmans (eds), Selling and Rejecting Politics in Early Modern Europe (Leuven: Peeters, 2007), pp. 119-34.

15. The Rijksmuseum owns a set of drawings and prints by Picart, drawn after the de Hooghe prints, and an original drawing by Romeyn de Hooghe of the 1672 event. 


\section{Imagineering}

16. Hale, 'Political Martyrs'.

17. Prolific producers of visual violence included Frans Hogenberg, Barend Dircksz, Otto van Veen, Claes Jansz. Visscher, Gaspar Boutats and Jan Luyken. Michel van Duijnen, “'Only the Strangest and Most Horrible Cases": The Role of Judicial Violence in the Work of Jan Luyken', Early Modern Low Countries Journal, 2:2 (2018), pp. 169-97.

18. Van Nierop et al., Romeyn de Hooghe.

19. De Hooghe's Bible illustrations also seem to show a preference for the violent Old Testament stories.

20. Wolfgang Cilessen, 'Der Spiegel der jeugd: Ein Kinderbuch als Medium der Geschichtserinnerung in den Niederlanden (1614-1813)', in Hans Peterse (ed.), Süss scheint der Krieg den Unerfahrenen: Das Bild vom Krieg und die Utopie des Friedens in der Frühen Neuzeit (Goüttingen: V\&R unipress, 2006), pp. 51-134; Barbara B. Diefendorf, Beneath the Cross: Catholics and Huguenots in Sixteenth-Century Paris (New York: Oxford University Press, 1991); Barbara B. Diefendorf, Saint Bartholomew's Day Massacre: A Brief History with Documents (Boston: Bedford/St. Martin, 2009); and Groesen, Representations of the Overseas World.

21. 'Wat Wreetheden, Moorderijen, Brantstichtingen, Plunderingen, Verwoestingen, Overtollige schattingen ende ander gheweldt, soo aen den Lichame, als aen der Conscientie, veel duysenden der goeder Inwoonderen deser Landen geleden hebben, ... : daer doch een yeder zijne Kinderen ende Kints Kinderen dit wel ernstlijck behoorde in te prenten'. Baudartius's Morghen-wecker der vrye Nederlantsche Provintien (1610) was informed by Le Reveille-Matin des Francois et de leurs voisins (1574, 'Wake-up call for the French and their neighbours'; translated into Dutch as Franse Morghen-wecker). Baudartius takes the model of the slaughter of the French Huguenots and transposes this to a report of the atrocities the Spanish had afflicted on the Dutch.

22. Re-mediation, already explored by Walter Benjamin in his essay 'Das Kunstwerk im Zeitalter seiner technischen Reproduzierbarkeit' (1935) is now generally considered a distinctly modern phenomenon, as a study by Jay David Bolter and Richard Grusin testified. Jay David Bolter and Richard Grusin, Remediation: Understanding New Media (Cambridge, MA: MIT Press, 1999). We consider the baroque as the pivot towards modernity in this respect.

23. See Rijksmuseum RP-P-1911-3670. In the original the text is 'Voyla les beaux exploits de ces coeurs inhumains / Ils ravagent par tout rien n'échappe à leur mains / L'un pour avoir de l'or, invente des Supplices, / L'autre à mil forfaits anime ses complices, / Et tous d'un mesme accord commettent méchamment / Le vol, le rapt, le meurtre, et le violement.' The translation is from Katie Hornstein, 'Just Violence: Jacques Callot's "Grandes Misères et Malheurs de la Guerre"', Bulletin of the University of Michigan Museums of Art and Archaeology, 16 (2005), pp. 29-48 (30).

24. When Abraham Bosse published his manual of etching in 1645 (Traicté des manieres de graver en taille douce dur l'airin, Paris: Bosse), spreading Callot's technical innovations to a wider European audience, he helped the technique of etching and printing to become popular, a tool to be used by all for all.

25. Dramatizing is used here as it is used in general in drama studies and consequently differs from dramatization as developed by one of the contributors: Frans-Willem Korsten, A Dutch Republican Baroque: Theatricality, Dramatization, Moment and Event (Amsterdam: Amsterdam University Press, 2017).

26. Marshall McLuhan, The Gutenberg Galaxy: The Making of the Typographic Man (Toronto: University of Toronto Press, 1962), p. 10.

27. Ibid. p. 24. 


\section{Cultural History}

28. ALCOA special page, Time, February 16, 1942, p. 59; see http://graphic-design.tjs-labs. com/show-picture?id=1118935951\&size=FULL.

29. Johannes Suitner, Imagineering Cultural Vienna: On the Semiotic Regulation of Vienna's Culture-Led Urban Transformation (Bielefeld: Transcript, 2015), p. 98.

30. Shaun Best, Leisure Studies: Themes and Perspectives (London: Sage, 2010), p. 196.

31. Paul Knox and Steven Pinch, Urban Social Geography: An Introduction (London: Routledge, 2010), p. 328.

32. Hornstein, 'Just Violence', p. 30.

33. See the title of Chapter 4 ('The Self as Eye') in: Celeste Brusati, Artifice and Illusion: The Art and Writing of Samuel van Hoogstraten (Chicago: University of Chicago Press, 1995), pp. 169-182.

34. See the title of Bernard Siegert's study on cultural techniques: Cultural Techniques: Grids, Filters, Doors, and Other Articulations of the Real, Geoffrey Winthrop-Young (transl.) (New York: Fordham University Press, 2015).

35. Michel Foucault, 'Technologies of the Self'. Luther H. Martin, Huck Gutman, Patrick Hutton (eds), Technologies of the Self: A Seminar with Michel Foucault (London: Tavistock, University of Massachusetts Press, 1988), pp. 16-49.

36. Stephen Greenblatt, Renaissance Self-Fashioning: From More to Shakespeare (Chicago: University of Chicago Press, 1980). This point was addressed in Jürgen Pieters's introduction to Critical Self-Fashioning: Stephen Greenblatt and the New Historicism (Frankfurt am Main: Lang, 1999), pp. 11-20, later worked out in Jürgen Pieters and Julie Rogiest, 'Self-fashioning in de vroegmoderne literatuur- en cultuurgeschiedenis: Genese en ontwikkeling van een concept', Frame, 22 (2009), pp. 43-59.

37. Although the play was not published until 1712, the title page seems to be from around 1673, which might indicate that Oudaen planned to publish the play quite soon after the murders.

38. J. Oudaen, 'Aantekeningen van de Moord- en mishandelinge der Heeren Cornelis en Jan de Wit den 20 Augusty 1672 in 's Gravenhage, door een oor- en ooggetuyge opgesteld'. This report was collected in the manuscript Stukken en Aantekeningen wegens... het verschrikkelijk ombrengen van de H(e)ren Jan, en Kornelis de Wit, verzameld...door $K$. van Alkemade (en) P. van der Schelling (Mss Royal Library The Hague), from which some excerpts can be found in René van Stipriaan, Ooggetuigen van de Gouden Eeuw in meer dan honderd reportages (Amsterdam: Prometheus, 2000), pp. 232-7.

39. Van Stipriaan, Ooggetuigen, p. 235.

40. Oudaen, 'Aantekeningen', pp. 236-7.

41. Van Stipriaan, Ooggetuigen, p. 260.

42. William S. Heckscher, Rembrandt's Anatomy of Dr. Tulp (New York: New York University Press, 1958), p. 32.

43. In 1611 the surgeons moved to the low building at the former Saint Anthony weighing house and in 1639 moved back to the building by the Nes, which the chamber of rhetoric had meanwhile left and where the city financed the construction of small permanent anatomical theatre. Julie V. Hansen, 'Resurrecting Death: Anatomical Art in the Cabinet of Dr. Frederik Ruysch', Art Bulletin, 78:4 (1996), pp. 663-79 (665).

44. Nicolaas ten Hoorn, Wegwijzer door Amsterdam (Amsterdam: author, 1713).

45. Florike Egmond, 'Execution, Pain and Infamy: A Morphological Investigation', in Florike Egmond and Robert Zwijnenberg (eds), Bodily Extremities: Preoccupations with the Human Body in Early Modern European Culture (Aldershot: Ashgate, 2003), pp. 92-128 (120).

46. Heckscher, Rembrandt's Anatomy, p. 28. 


\section{Imagineering}

47. Jonathan Sawday, The Body Emblazoned: Dissection and the Human Body in Renaissance Culture (London: Routledge, 1995), p. 62. In his book, Jonathan Sawday meticulously describes the title page of Vesalius's De Humani Corporis Fabrica (1543) and shows how everybody is watching everybody else, just like in early modern theatre (see Ch. 4: 'Execution, Anatomy, and Infamy: Inside the Renaissance Anatomy Theatre').

48. Hansen, 'Resurrecting Death', p. 667; José van Dijck, 'Digital Cadavers and Virtual Dissection', in Maaike Bleeker (ed.), Anatomy Live: Performance and the Operating Theatre (Amsterdam: Amsterdam University Press, 2008), pp. 29-48 (39); and Christine Quigley, Dissection on Display: Cadavers, Anatomists and Public Spectacle (Jefferson, NC: McFarland, 2012), p. 149.

49. Sawday, Body Emblazoned.

50. Annet Mooij, De polsslag van de stad: 350 jaar academische geneeskunde in Amsterdam (Amsterdam: Arbeiderspers, 1999), p. 83.

51. 'Het natuurlijk wesen zoodanig wedergegeven aan de afgestorven lighaamen, dat men se van een levendig en slapend mensch niet kan onderscheyden, zijnde alle ledematen, die in afgestorven menschen onbeweeglijk zijn in deze nauw beweeglijk als een levende mensche.' Quoted in Jan C. C. Rupp, 'Theatra anatomica: Culturele centra in het Nederland van de zeventiende eeuw', in Joost J. Kloek and Wijnand W. Mijnhardt (eds), De productie, distributie en consumptie van cultuur (Amsterdam: Rodopi, 1991), pp. 13-36 (27). The original quote is from Frederik Ruysch, Alle de ontleed-genees-en heelkundige werken (Amsterdam: Janssoons van Waesberge, 1744), vol. 2, p. 9. For an analysis of the anatomical art of Ruysch, see Luuk Kooijmans, De doodskunstenaar: De anatomische lessen van Frederik Ruysch (Amsterdam: Bert Bakker, 2004).

52. Govard Bidloo, Anatomia humani corporis (Amsterdam: Joannis a Someren, 1685).

53. Bidloo's work was highly contested, as was his person. Ruysch criticized Bidloo's work, as did many others. Leiden students complained that Professor Bidloo hardly lectured at all. His involvement in the theatre did not last long: Bidloo was publicly exposed as 'king Midas', the ruin of the theatre. The fierce pamphlets and satirical plays that Bidloo published also guaranteed that his persona would be contested. Kooijmans, De doodskunstenaar, pp. 205-59.

54. Kornee van der Haven, Achter de schermen van het stadstoneel: Theaterbedrijf en toneelpolemiek in Amsterdam en Hamburg 1675-1750 (Zutphen: Walburg Pers, 2008), p. 172.

55. Recently, Joost van den Vondel, traditionally seen as a classicist playwright, has been considered in principally baroque terms. See Frans-Willem Korsten, Sovereignty as Inviolability: Vondel's Theatrical Explorations in the Dutch Republic (Hilversum: Verloren, 2009); and Korsten, Dutch Republican Baroque. The traditional vision is partly based on a bias towards original Dutch plays, which ignored the impressive amount of, for instance, translations and adaptations of Spanish plays that were staged in the Amsterdam theatre, which could be very violent. See ON STAGE, a database developed by a team from the University of Amsterdam which maps all the plays staged at the Amsterdam theatre between its opening in 1637 and 1800 (ONSTAGE Online Datasystem of Theatre in Amsterdam from the Golden Age to the present, http://www.vondel.humanities.uva.nl/onstage, accessed 17 December 2020/). Kim J. Jautze et al., 'Spaans theater in de Amsterdamse Schouwburg (1638-1672): Kwantitatieve en kwalitatieve analyse van de creatieve industrie van het vertalen', De Zeventiende Eeuw, 32 (2016), pp. 12-39. 


\section{Cultural History}

56. Initially, Bidloo had close contacts with members of Nil Volentibus Arduum and visited their meetings. Later on, he became one of the opponents of that society and his theatrical output and interest seem to have been quite spectacular; compare Bidloo's musical play Het zegepraalende Oostenryk, of the verovering van Offen (The victorious Austria, or the recapture of Buda) (1686). Rina Knoeff, 'Govert Bidloo (1649-1731): Onbemind maakt Onbekend', in Jetze Touber and Marjan Brouwer (eds), De kaper, de kardinaal en andere markante Nederlanders (Hilversum: Verloren, 2010), pp. 85-94; and Orsalya Réthelyi, 'Buda's Reconquest (1686) and the Image of Hungarians, Ottomans and Habsburgs in Seventeenth-Century Dutch Drama', in Kees Teszeleszky (ed.), A Divided Hungary in Europe: Exchanges, Networks and Representations, 1541-1699, vol. 3 (Newcastle: Cambridge Scholars, 2014), pp. 167-94.

57. In 1600 Den Spieghel des hoochmoets (The Mirror of pride) by Jacob Duym, an adaptation of Seneca's Troades, was included in Een spieghelboek (A mirror book) and staged by a Flemish theatre group.

58. On Vos, see Nina Geerdink, De sociale verankering van het dichterschap van Jan Vos (1610-1667) (Hilversum: Verloren, 2012).

59. Karel Vanhaesebrouck, 'Barok en Classicisme', in Thomas Crombez et al. (eds), Theater: Een westerse geschiedenis (Tielt: Lanoo, 2015), pp. 120-44 (133).

60. W. M. H. Hummelen, Inrichting en gebruik van het toneel in de Amsterdamse schouwburg van 1637 (Amsterdam: Noord-Hollandsche uitgeversmaatschappij, 1967).

61. Jan Vos, Aran en Titus, of Wraak en Weerwraak: Treurspel (Amsterdam: D. vander Stichel et al., 1641).

62. Sawday, Body Emblazoned, p. 2.

63. See website Vincent Glowinski, http://www.vincentglowinski.com/fr/30/interdits, accessed 15 November 2019.

64. Henri Lefebvre, The Production of Space, Donald Nicholson-Smith (transl.) (Oxford: Blackwell, 1991), p. 39. 


\section{Your short guide to the EUP Journals Blog http://euppublishingblog.com/}

A forum for discussions relating to Edinburgh University Press Journals

\section{The primary goal of the EUP Journals Blog}

To aid discovery of authors, articles, research, multimedia and reviews published in Journals, and as a consequence contribute to increasing traffic, usage and citations of journal content.

\section{Audience}

Blog posts are written for an educated, popular and academic audience within EUP Journals' publishing fields.

\section{Content criteria - your ideas for posts}

We prioritize posts that will feature highly in search rankings, that are shareable and that will drive readers to your article on the EUP site.

\section{Word count, style, and formatting}

- Flexible length, however typical posts range 70-600 words.

- Related images and media files are encouraged.

- No heavy restrictions to the style or format of the post, but it should best reflect the content and topic discussed.

\section{Linking policy}

- $\quad$ Links to external blogs and websites that are related to the author, subject matter and to EUP publishing fields are encouraged, e.g.to related blog posts

\section{Submit your post}

Submit to ruth.allison@eup.ed.ac.uk

If you'd like to be a regular contributor, then we can set you up as an author so you can create, edit, publish, and delete your own posts, as well as upload files and images.

\section{Republishing/repurposing}

Posts may be re-used and re-purposed on other websites and blogs, but a minimum 2 week waiting period is suggested, and an acknowledgement and link to the original post on the EUP blog is requested.

\section{Items to accompany post}

- A short biography (ideally 25 words or less, but up to 40 words)

- A photo/headshot image of the author(s) if possible.

- Any relevant, thematic images or accompanying media (podcasts, video, graphics and photographs), provided copyright and permission to republish has been obtained.

- Files should be high resolution and a maximum of $1 \mathrm{~GB}$

- Permitted file types: jpg, jpeg, png, gif, pdf, doc, ppt, odt, pptx, docx, pps, ppsx, xls, xlsx, key, mp3, m4a, wav, ogg, zip, ogv, mp4, m4v, mov, wmv, avi, mpg, 3gp, $3 g 2$. 